Preference is given to letters commenting on contributions published recently in the JRSM. They should not exceed 300 words and should be typed double spaced

\section{Human endogenous retroviruses in health and disease}

In his excellent and comprehensive review on human endogenous retroviruses (HERVs), Frank Ryan (December 2004, $J R S M^{1}$ ) introduces a subject that could well become of central importance in 21 st century medicine. To take one example, HERVs could provide the key to understanding how environmental changes associated with improved hygiene in the industrialized nations appear to be associated with the upsurge of certain diseases, notably autoimmunity, allergy and cancer.

In this context, the risk of childhood leukaemia has been linked to hygiene-related factors, ${ }^{2}$ and an extensive multicentre study showed that the risk of melanoma is reduced by certain vaccinations-BCG and vaccinia-as well as some uncommon but serious infectious diseases early in life. ${ }^{3,4}$ Furthermore, the prognosis of melanoma patients who had previously received $\mathrm{BCG}$ and/or vaccinia was significantly better than that of unvaccinated patients. ${ }^{5}$ There is evidence that many cases of melanoma are associated with the expression of HERV-encoded proteins that induce malignant change by altering the intracellular redox potential. The 'Achilles' heel' of this process is that a HERV-derived nonapeptide or decapeptide epitope, HERV$\mathrm{K}-\mathrm{MEL}$, is expressed on the surface of the cell undergoing malignant transformation, in principle enabling it to be recognized by the immune system. ${ }^{6}$ We have shown that BCG, vaccinia and the agents causing the infectious diseases that afford protection against melanoma have analogues of the HERV-K-MEL epitope and we have therefore postulated that these vaccinations or infections generate populations of cross-reactive $\mathrm{T}$ cells able to engage in immunosurveillance and effect repair or destruction of melanocytes expressing this antigen. ${ }^{7}$

Accordingly, improvements in hygiene in the industrially developed countries resulting in less infectious diseases, together with the abandonment of vaccinia vaccination in all such countries and BCG in many, could be having a deleterious effect on the development of effective immunosurveillance against at least one type of cancer.

Further epidemiological studies to determine whether malignant disease other than melanoma and leukaemia are affected by hygiene-related factors, as well as laboratory studies to confirm the molecular basis of carcinogenesis and immunosurveillance, are required. Such studies could lead immunotherapeutic agents based on the relevant HERVencoded epitopes or on micro-organisms, including some currently available vaccines, which induce cross-reacting immune responses to such epitopes.

\author{
John M Grange ${ }^{1}$ \\ Bernd Krone ${ }^{2}$ \\ Klaus Kölmel ${ }^{2}$ \\ ${ }^{1}$ Centre for Infectious Diseases and International Health, University College \\ London, UK; ${ }^{2}$ Faculty of Medicine, University of Göttingen, Germany \\ E-mail: sophia@hagia.freeserve.co.uk
}

\section{REFERENCES}

1 Ryan FP. Human endogenous retroviruses in health and disease: a symbiotic perspective. J R Soc Med 2004;97:560-5

2 Perrillat F, Clavel J, Auclerc MF, et al. Day-care, early common infections and childhood acute leukaemia: a multicentre French casecontrol study. Br J Cancer 2002;86:1064-9

3 Pfahlberg A, Kölmel KF, Grange JM, et al. Inverse association between melanoma and previous vaccinations against tuberculosis and smallpox: results of the FEBIM study. J Invest Dermatol 2002;119:570-5

4 Krone B, Kölmel KF, Grange JM, et al. Impact of vaccinations and infectious diseases on melanoma risk - evaluation of an EORTC casecontrol study. Eur J Cancer 2003;39:2372-8

5 Kölmel KF, Grange JM, Krone B, et al. Prior immunisation of patients with malignant melanoma with vaccinia or BCG is associated with better survival. An European Organization for Research and Treatment of Cancer cohort study on 542 patients. Eur J Cancer 2005;41:118-25

6 Schiavetti F, Thonnard J, Colan D, et al. A human endogenous retroviral sequence encoding antigen recognized on melanoma by cytolytic T lymphocytes. Cancer Res 2002;62:5510-16

7 Krone B, Kölmel KF, Henz BM, Grange JM. Protection against melanoma by vaccination with Bacille Calmette-Guérin (BCG) and/or vaccinia: an epidemiology-based hypothesis on the nature of a melanoma risk factor and its immunological control. Eur J Cancer 2005;41:104-17

Symbiogenesis certainly removes the scientific straitjacket from the purely darwinistic interpretation of evolution. ${ }^{1}$ It recognizes that cooperation is a strong developmental principle. Fred Hoyle, in his 1983 Lloyd Roberts Lecture at the RSM,$^{2}$ commented on the prevailing confusion whereby 'evidence for evolution has become misinterpreted as evidence for Darwinian theory'.

Frank Ryan ${ }^{3}$ suggests that about $50 \%$ of the human genome is a legacy of human endogenous retroviruses (HERVs) and their fragments. These have invaded as exogenous viruses throughout the 4 billion years of biological history and have remained intracellular to become symbiotic viruses permanently transmitted vertically. Many of the thousands of HERVs in each cell have brought with them useful or even essential biological functions such as the formation of syncytium of the human placenta. Without the ERVs humanity would not survive.

What is the origin of these exogenous retroviruses, and for that matter bacteria, which seem to have become mitochondria in the protozoan stage of development? Hoyle presented astrophysical evidence that the content 
of comet efflux was remarkably lifelike. He noted Delsemme's analysis ${ }^{4}$ of the ratios of oxygen, hydrogen, carbon and nitrogen in the comet efflux, which were $\mathrm{O}: \mathrm{H}: \mathrm{C}: \mathrm{N}=1: 1.8: 0.32: 0.08$. After much searching he found the ratios for dried bacteria to be the best biological match-1 : $2.2: 0.5: 0.05$. No other celestial body had anything like this composition. Furthermore Hoyle presented strong statistical arguments for the impossibility of chance creation of our 2000 or so enzymes for natural selection to choose from - a figure he puts at 1 in $10^{40000}$, 'which is more than all the atoms in all the galaxies that we know of'.

In 1986 Hoyle became more specific ${ }^{5}$ observing that the periodicity of pertussis infections every 3.5 years is the same as the orbital periodicity of comet Enke. The earth crosses the streams of particles from comet Enke on 20 October to 25 November and from 23 June to 7 July each year. Also the great flu epidemics have occurred when comet Enke has been nearest to Earth. As Ryan points out, there is little doubt now that viruses and viral fragments contribute hugely to our genome. The only question is where do they come from? Hoyle made a strong case for certain comets and suggested a space probe to comet Enke. NASA has just announced a deep impact mission to comet Tempel I. It may be that all comets do not contribute to this viral and bacterial effluence. We should know within a few months whether comet Tempel I does.

\section{Anthony Kenyon}

5403 Liard Street, Fort Nelson, BC, Canada VOC 1R0

E-mail: akenyon@northwestel.net

\section{REFERENCES}

1 Fox R. Symbiogenesis. J R Soc Med 2004;97:559

2 Hoyle F. From virus to cosmology. J R Soc Med 1983;76:99-110

3 Ryan F. Human endogenous retroviruses in health and disease; a symbiotic perspective. J R Soc Med 2004;97:560-5

4 Delsemme AH. In: Ponnamperuma C, ed. Comets and the Origin of Life. Dordrecht: Reidel, 1977

5 Hoyle F. Halley's comet and others: the bacterial starshells.J R Soc Med 1986;79:691-3

\section{Brain imaging in fatigue syndromes}

In their article on the incidence of fatigue symptoms and diagnoses (December 2004, JRSM ${ }^{1}$ ) Gallagher and coworkers cite Wessely's view that 'chronic fatigue is one of a diverse group of physical symptoms that have long defied satisfactory explanation by doctors'. ${ }^{2}$ Recent developments in functional MRI have pointed to a more scientific approach in diagnosing these conditions. Gracely et al. ${ }^{3}$ demonstrated augmented pain processing in fibromyalgia with increased signals in the anterior cingulate cortex during fMRI. Furthermore, in order to ascertain the veracity of subjective claims, fMRI indicates that attempted deception will cause increased activity in the ventrolateral, prefrontal, anterior cingulate and premotor cortex. ${ }^{4-6}$

\section{E Berger}

Montreal Neurological Hospital, McGill University, Montreal, Canada

E-mail: berger@oceanwide.com

\section{REFERENCES}

1 Gallagher AM, Thomas JM, Hamilton WT, White PD. Incidence of fatigue symptoms and diagnoses presenting in UK primary care from 1990 to 2001. J R Soc Med 2004;97:571-5

2 Wessely S, Nimnuan C, Sharpe M. Functional somatic syndromes: one or many? Lancet 1999;354:936-9

3 Gracely RH, Petzke F, Wolf JM, Clauw DJ. Functional magnetic resonance imaging evidence of augmented pain processing in fibromyalgia. Arthritis Rheum 2002;46:1333-43

4 Langleben DD, Schroeder L, Maldjian JA, et al. Brain activity during simulated deception: an event related functional magnetic resonance study. Neuroimage 2002;15:727-32 [Rapid Communication 1-6]

5 Lee TM, Liu HL, Tan LH, et al. Lie detection by functional magnetic resonance imaging. Human Brain Mapping 2002;15:157-64

6 Spence SA, Farrow TFD, Herford AE, Wilkinson ID, Zheng Y, Woodruff PWR. Behavioural and functional anatomical correlates of deception in humans. Neurorep 2001;12:2849-53

\section{Conjoined twins, delivery and the memory of medicine}

The book by Alice Dreger reviewed by Dr Kessel in the December $2004 J R S M^{1}$ is a wonderful portrayal of the painful curiosity, acclaim, and social stigma variously associated with conjoined twins, as well as the role of the heroic operations developed for their separation. Yet no single volume can include all cases of conjoined twins. Indeed, one set is regrettably underappreciated by modern sciences - the Blazek sisters of Bohemia (1878-1922). They represent an extreme manifestation of the terminal monogenital pygopagus subset of conjoined twins, with fusion of sacrum/pelves and a combined (septated) vagina. Indeed, the Blazek sisters stand out as the only known conjoined twins who themselves conceived and delivered a baby (a normal healthy male). Truly unique in the archive of medicine, one sister continued to menstruate through a shared vagina until the 32nd week of her conjoined twin's pregnancy. While the better known 'Siamese twins' Chang and Eng Bunker left historians a vast cultural legacy in all manner of poetry, portraiture and song, traces of the Blazek sisters (who likwise toured and exhibited extensively) have now all but vanished. Why has their story been forgotten? Although the Blazek's weaker marketing strategy might be to blame, the paucity of formal reports describing these twins in the medical literature certainly contributes to their present obscurity. ${ }^{2,3}$ Surprisingly, many 'comprehensive' obstetrics textbooks still miss this highly unusual reproductive accomplishment even in their footnotes. 
Nevertheless, in physiology it is from observations of the extreme where most is learned about what is possible among the ordinary. As the Blazek story slips into oblivion, our field risks losing another reminder that, even in the era before complex surgery, conjoined twins were not always consigned to an incomplete reproductive career.

\section{E Scott Sills}

Atlanta, USA 30342

E-mail: Dr.Sills@ivf.com

\section{REFERENCES}

1 Kessel R. One of Us [Book review]. J R Soc Med 2004;97:603-4

2 Schierhorn H. Egon Erwin Kisch und die Geschwister Blazek: ein Bietrag zur Geschichte der Teratologie. Anat Anz (Jena) 1985;160:35365

3 Kabelik J. Srostlé sestry Blažkovy. Cas Lek Cesk 1975;114:1278-81

\section{Access to scrotal ultrasonography}

In their letter about access to scrotal ultrasonography (November 2004, JRSM ${ }^{1}$ ) Mr Pocock and his colleagues refer to a large number of inappropriate primary care referrals. Like his, our service has noted increasing referrals for scrotal ultrasound and our assumption was that the majority of these arose from primary care. However, our audit of 569 ultrasound scans performed in the 18 month period from 1 April 2000 to 30 September 2001 showed that general practitioners (GPs) accounted for only 129 (22.7\%); by far the largest source of requests was urologists $(n=282,49.6 \%)$, followed by general surgeons $(n=109$, $19.2 \%)$. Further analysis of the secondary care requests showed that $46.3 \%$ were by consultants, $34.7 \%$ specialist registrars or staff grades and 19\% junior medical staff.

The median wait for scrotal ultrasound was 36 days, leading to a range of 'journey times' from initial GP referral to diagnosis at orchidectomy up to 127 days: in total, 11 patients in this period were diagnosed by this modality with testicular malignancy. To improve this, we identified the most timely and direct route for referrals, nominated a lead uro-oncologist, and instituted a reduction in the number of clinicians who could request scrotal ultrasonography. These scans are now reported the same day and if testicular tumour is suspected on ultrasound, the para-aortic nodes, kidneys and liver are visualized at the same investigation. The most important point may be to account for the relatively low number of patients diagnosed with testicular tumours both in our audit and in the original paper by Allen et al. (June $2004 J R S M^{2}$ ) which looked specifically at two-week-wait referrals, with only 1 positive diagnosis via this route. Reviewing our practice in the past 12 months we find that 15 patients have been diagnosed with testicular tumours (seminoma 10, teratoma 3, non- two-week referral; 3 were by urgent GP referral, 1 by routine GP referral, 2 by direct GP ultrasound request, with 1 each from oncology (for a second testicular tumour) and general surgery. Reassuringly, median time from ultrasound to inguinal orchidectomy was only 13 days (range 2-19).

This is the group of patients for whom one would imagine the two-week-wait-referral mechanism was designed specifically to help. It is of concern, then, that at least half our patients who are found to have testicular tumours are still not being referred through this route. However, by streamlining ultrasonography practices, one can greatly lessen journey times from referral to definitive surgery.

\section{Bruce Sizer}

Donna Booton

Martin Gould

John Corr

Essex County Hospital, Lexden Road, Colchester CO3 3NB, UK

\section{REFERENCES}

1 Pocock RD, Stott MA, Crundwell MC, Watkinson A, Thomas R, Cooke J, Harington J. Access to scrotal ultrasonography. J R Soc Med 2004;97:558

2 Allen D, Popert R, O’Brien T. Two-week-wait cancer initiative in urology: useful modernization? J R Soc Med 2004;97:279-81

\section{Myocardial infarction after aspirin}

Dr Fox and his colleagues (January 2004, JRS $M^{1}$ ) describe a patient who had a myocardial infarction in the course of a severe allergic reaction to aspirin. They suggest that the observed coronary vasospasm could have been due either to aspirin directly or to massive release of catecholamines during the anaphylactic reaction. In my opinion, the latter explanation is more likely. There are many reports of coronary vasospasm in severe anaphylaxis - for example, in allergic reactions to drugs such as amoxicillin ${ }^{2}$ and naproxen ${ }^{3}$ and even after a bee sting. ${ }^{4}$ Physicians should be cautious in using epinephrine in these circumstances since it can worsen the vasospasm. ${ }^{5}$

\section{S Rachapalli}

Rheumatology and General Medicine, Ashford Hospital, Middlesex TW15 3AA, UK E-mail: satish@rachapalli.com

\section{REFERENCES}

1 Fox DJ, Gray TP, Fath-Ordoubadi F. Myocardial infarction after aspirin treatment. J R Soc Med 2005;98:21-3

2 Lopez-Abad R, Rodriguez F, Garcia-Abujeta JL, Martin-Gil D, Jerez J. Myocardial ischemia due to severe amoxicillin allergy. J Investig Allergol Clin Immunol 2004;14:162-4

3 Cistero A, Urias S, Guindo J, et al. Coronary artery spasm and acute myocardial infarction in naproxen associated anaphylactic reaction. Allergy 1992;47:576-8 
4 Magadle R, Weiner P, Waizman J, Pelled B. Acute myocardial infarction after honeybee sting. Harefuah 2000;138:543-5, 614

5 Karch SB. Coronary artery spasm induced by intravenous epinephrine overdose. Am J Emerg Med 1989;7:485-8

\section{Surcharge for paper version of the JRSM}

It was with a mixture of sadness and disappointment that, at the last time my subscription to the RSM became due, I was informed that, if I wished to continue to receive the paper copy of the JRSM, I should have to pay an additional fee of $£ 12$ a year. I would not deny that the $J R S M$ is well worth $£ 12$ a year but that is not the point. The reason given for the change in policy was that most Fellows now read the $J R S M$ online. How many opinions were sought was not revealed, and I believe the claim to be questionable. Moreover, I suspect that those who took this unfortunate decision gave no thought to those who are retired. We do not have computers, paper, ink, cartridges and everything else provided by the employer. Perhaps more importantly, the retired probably prefer to do their reading away from the screen - in an armchair, in bed, in the bath, and particularly when travelling. These options are not available if one is confined to an online version.

Several organizations will have considered substituting the web for a paper version of their journal. The RSM is the only one of which I know that has adopted the policy. As a member of the BMA, the Royal College of Anaesthetists and the Association of Anaesthetists, I receive a paper version of their journal(s) as part of my subscription as well as a paper version for three overseas specialist organizations. In every case these journals are available on the web but the cost of a paper version continues to be included in the relevant annual subscription. And this is only within my specialty.

Having been a member of the RSM for nearly 50 years and having been retired since 1995, I resent being asked for additional money for something that I have always had as part of my RSM subscription. Furthermore, I resent having this charge imposed on me with no warning other than the annual subscription renewal form. Is the RSM so short of money that it needs to make this penny-pinching economy? If so, let it be honest and explain why an increase in the subscription rate is not preferable. As a matter of principle, I have declined to pay extra for the JRSM and thus miss out on one of the best medical journals available.

\section{John Zorab}

Bristol, UK

E-mail:JZorab@compuserve.com

For those who can seldom use the handsome metropolitan facilities of the RSM and have no need for its IT facilities a particular benefit of membership is the JRSM, with its excellent and wide-ranging review of the medical scene. To impose a surcharge on Fellows who prefer (and possibly need) the convenience of the printed page, rather than the online version, is not just damaging to the Society's known reputation for inclusivity but also a disrecommendation to further recruitment. Council should reconsider this misguided attempt to appease the auditors.

\section{H M C Corfield}

Crewkerne, UK

\section{Honorary Editor's reply}

It was with deep misgivings that the RSM's Honorary Officers recommended to Council a package of savings that included putting a surcharge on the paper version of the $J R S M$. In addition we have reduced the printing costs of $R S M$ News. We sincerely hope that this will not reduce the influence of the JRSM, but it was thought that this would do less damage to the Society than a further hike in the Fellowship subscription. Several other thrift measures are being taken to ease our financial position to pay for the new facilities at No. 1 Wimpole Street which will enable us to compete and retain members in the highly competitive world of the learned societies, colleges and trusts' educational programmes. I can assure Dr Zorab and Dr Corfield that the Honorary Officers will review any effects of these measures, the response of the members, and be flexible in the future.

\section{Peter McDonald}

Honorary Editor, The Royal Society of Medicine

\section{Achilles tendinopathy}

Professor Ferns (December 2004, JRSM ${ }^{1}$ ) recommends looking at the eyes as well as the legs in Achilles tendinopathy, to detect the corneal arcus of familial hypercholesterolaemia. In my opinion, the serum lipids should be checked in all cases of Achilles tendinitis, whether unilateral or bilateral. I have seen several patients whose hypercholesterolaemia presented with Achilles tendinitis, and not all had eye signs.

\section{G R Clarke}

Department of Rheumatology, Harold Wood Hospital, Romford RM3 OBE, UK E-mail: Geoffrey.clarke@bhrhospitals.nhs.uk

\section{REFERENCE}

1 Ferns G. Achilles tendinopathy. J R Soc Med 2004;97:608

\section{Sir Thomas Browne's birthday}

The mistaken belief that Sir Thomas Browne was born on 19 October 1605, exactly 77 years before his death, originated in the anonymous biography preceding Browne's 
Posthumous Works, ${ }^{1}$ which included his musings on such a rare coincidence of dates. It gathered credence by frequent repetition, as in Professor Breathnach's appreciative memoir (January 2005, $J R S M^{2}$ ), and has endured for nearly 300 years. Yet it should have been abandoned by now. ${ }^{3}$ Sir Thomas himself, in answer to John Aubrey's request, wrote on 24 August 1672: 'I was borne Novemb. 19, 1605'.4 There is no reason to doubt his word, which was accepted by Anthony Wood for the first biography ${ }^{5}$ and is affirmed in the recent Oxford Dictionary of National Biography. ${ }^{6}$

\section{Charles Morris}

Terrysfield, Downe, Orpington BR6 7JT, UK

\section{REFERENCES}

1 Browne T. Posthumous Works. London: E Curll \& R Gosling, 1712:i-xxiii

2 Breathnach C. Sir Thomas Browne (1605-1682). J R Soc Med 2005;98:33-6

3 Morris GCR. Sir Thomas Browne's Nativity. Notes \& Queries. 1983;30:420-1

4 Bodleian Library. MS Aubrey: 12, f. 53

5 Wood A. Athenae Oxonienses. London: T Bennet, 1691-2: ii, 535

6 Robbins RH, Browne, Sir Thomas. Oxford Dictionary of National Biography. Oxford: Oxford University Press, 2004: 8, 206-17

Professor Breathnach has made an elegant start to the Browne quatercentenary celebrations. Readers may be interested to know that a celebration is to be held in Norwich on 19-20 October this year. The programme includes: an academic symposium (in which Sir Keith Thomas, Dr Trevor Hughes, Professor Harold Cook and the Rev Reginald Askew, will be speakers); a concert of 17th century and other relevant music with selected readings of Browne's writings in Norwich Cathedral (given by the Keswick Hall Choir conducted by Mr John Aplin); an exhibition of Browne memorabilia in the County Archive
Centre; and a service of thanksgiving in St Peter Mancroft Church (Browne's place of worship and of his interment); a conducted educational tour of Browne's Norwich; and a formal luncheon. Further details can be obtained from our website [http://www.uea.ac.uk/his/events/browne.shtml].

\section{B A Ross}

\section{R Y Ball}

Norfolk and Norwich Hospital, Norwich, UK

Professor Breathnach comments on Sir Thomas Browne's unfailing toleration. One of those greatly influenced by Browne's writings, especially Religio Medici, was Sir William Osler. Osler believed in a good general education for doctors and in Aequanimitas, ${ }^{1}$ published 100 years ago last year, he recommended the following books or authors for study: Shakespeare, Montaigne, Marcus Aurelius, Don Quixote, Plutarch, Emerson, Oliver Wendell Holmes and Religio Medici. Osler was influenced by the style of Browne's writings - 'The pomp of his sentences and the wealth of allusions' as described by Lytton Strachey. ${ }^{2}$ The books and authors recommended by Osler could all be profitably read by today's medical students as part of their liberal education. The themes of Religio Medici - the mystery of creation, disapproval of racial and religious bigotry and the virtues of charity — seem all too relevant 400 years on.

\section{Arpan K Banerjee}

Birmingham Heartlands and Solihull Hospitals NHS Trust, Birmingham B9 5SS, UK

E-mail: arpan.banerjee@heartsol.wmids.nhs.uk

\section{REFERENCES}

1 Osler W. Aequanimitas. London: Lewis, 1904

2 Strachey L. Literary Essays: Books and Persons. London: Chatto 